\title{
繰返し曲げを受ける鋼梁のエネルギー吸収能力 \\ ENERGY ABSORPTION CAPACITY OF STEEL BEAMS SUBJECTED TO CYCLIC BENDING MOMENT
}

\author{
山崎真司 ${ }^{* 1}$, 見波 進*2 \\ Shinji YAMAZAKI and Susumu MINAMI
}

\begin{abstract}
It may well be that in cases where huge long period ground motions are input into a high-rise building structure, its members will be subjected to many cyclic loading in plastic range. This study was carried out with the object of making clear the energy absorption capacity of steel beams subjected to cyclic bending moment. A series of tests were conducted under the condition of various types of loading sequence. On the basis of test results, the authors proposed a method for estimating the energy absorption capacity of steel beams subjected to arbitrary cyclic bending moment.
\end{abstract}

Keywords : Cyclic loading, Energy absorption capacity, Loading sequence, Local buckling, Fracture 繰返し載荷, エネルギー吸収能力, 載荷履歴, 局部座屈, 破断

\section{1 序}

梁崩壊型骨組の耐震性能を評価するためには梁部材のエネルギー 吸収能力を知る必要がある、鋼梁のエネルギー吸収能力は端部仕口 部の破断あるいは板要素の局部座屈によって限界づけられる場合が 多いが, 両者の場合についてこれまで多くの研究が行われ例え(゙1) 4), 基本的な力学特性について明らかにされている.

梁部材に関する既往の実験的研究においては, 単調載荷または漸 増変位振幅繰返し載荷が基本的に用いられている.これまで地震時 における主要な繰返し数は数回程度であり，このような実験結果か ら地震時のエネルギー吸収能力は推定できると考えられていた ${ }^{5)}$. しかし, 海溝型巨大地震時に発生する長周期地震動が高層建物に入 力する場合には多数回の塑性繰返しを受ける可能性があり,このよ うな場合のエネルギー吸収能力の評価法については不明な点が多 (6).

繰返し載荷履歴が $\mathrm{H}$ 形断面鋼梁のエネルギー吸収能力に与える影 響に着目した実験的研究は少ないが, 主な研究として以下がある. 筆者ら ${ }^{77,8)}$ は, エネルギー吸収能力が局部座屈あるいは仕口部の破 断によって限界づけられる場合を対象とし, 載荷履歴を実験変数と した試験を行い，単調載荷時のエネルギー吸収量を用いて絽返し載 荷時のエネルギー吸収量を評価する方法について考察している，松 本ら 9) は同一形状の試験体に対して載荷パターンを変化させた実験 を行い，骨格部およびバウシンガー部で吸収するエネルギーについ
て分析している. 山田ら ${ }^{10)}$ は, 同一形状の試験体を用いて漸増変位 振幅, 漸減変位振幅および定振幅載荷実験を行い, 載荷履歴がエネ ルギー吸収能力に及ぼす影響を考察している，なお，文献 9)，10)の 研究では, エネルギー吸収能力が仕口部の破断によって限界づけら れる場合を対象としている.

本論文は載荷履歴が鋼梁のエネルギー吸収能力に及ぼす影響を明 らかにすることを目的とする. 先ず, 端部仕口部の破断あるいは板 要素の局部座屈によってエネルギー吸収が限界づけられる場合を 対象とし, 載荷履歴を変数として行った一連の試験結果を示す. 次 に，曲げの正または負側の半サイクルで吸収するエネルギーを振幅 の指標とし, 振幅と安定限界に至るまでの繰返し数の関係を求める. この関係を用い, 単調載荷時あるいは標準的漸増変位振幅繰返し載 荷 ${ }^{11)}$ 時のエネルギー吸収能力に基づき任意の繰返し載荷時のエネル ギー吸収能力を予測する方法について考察する.

\section{2 実験方法}

\section{1 試験体}

試験体形状を図 1 に示す。片持梁形式の試験体で，片持載荷長は $1 \mathrm{~m}$ である. 梁断面は SM490A 鋼板を用いた溶接組立 H 形断面で, 端部フランジは全試験体共完全溶込み溶接接合とし，端部ウェブは 隅肉溶接接合またはHTB 接合とした。

溶接部の詳細を図 2 に示す. 施工時においてフランジ溶接部の始
(本論文の一部は文献 7)，8）に発表した。）

*1 東京電機大学大学院理工学研究科 教授. 工博

*2 首都大学東京大学院都市環境科学研究科 助教・博士(工学)
Prof., Graduate School of Science and Engineering, Tokyo Denki University, Dr. Eng. Assistant Prof., Graduate School of Urban Environmental Sciences, Tokyo Metropolitan University, Dr. Eng. 
表 1 試験体一覽

\begin{tabular}{|c|c|c|c|c|c|c|c|c|c|c|c|c|c|c|c|c|c|c|}
\hline 試験体名 & 梁断面 & $b / t_{f}$ & $d / t_{w}$ & $\begin{array}{l}\text { ウェブ } \\
\text { 接合 }\end{array}$ & リブ & $\begin{array}{l}\text { 崩買 } \\
€\end{array}$ & $\alpha$ & $\eta_{e}^{+}$ & $\eta_{e}^{-}$ & $\eta_{e}$ & $N_{e}^{+}$ & $N_{e}^{-}$ & $N_{e}$ & $\overline{\Delta \eta}_{e}$ & $\overline{\frac{\Delta \eta_{e}}{\Delta \eta_{I}}}$ & $\frac{N_{e}}{N_{I}}$ & $\frac{\overline{\Delta \eta_{e}}}{\eta_{0}}$ & $\gamma$ \\
\hline G1WN-12 & \multirow{2}{*}{$120 \times 4.5 \times 9$} & \multirow[b]{2}{*}{6.67} & & & & L1 & 1.15 & 17.2 & 19.5 & 36.8 & 5 & 5 & 10 & 3.68 & 1.00 & 1.00 & - & 0.53 \\
\hline G1WN-14 & & & & & & L1 & 1.13 & 21.5 & 18.5 & 40.0 & 8 & 7 & 15 & 2.67 & 0.73 & 1.50 & - & 0.54 \\
\hline G1BR-I2 & \multirow{2}{*}{$\mathrm{H}-300 \times 120 \times 4.5 \times 9$} & \multirow{2}{*}{6.67} & \multirow{2}{*}{62.7} & \multirow{2}{*}{ HTB } & \multirow[b]{2}{*}{ 有 } & F1 & 1.05 & 5.2 & 5.3 & 10.5 & 3 & 3 & 6 & 1.75 & 1.00 & 1.00 & - & 0.51 \\
\hline G1BR-I4 & & & & & & F1 & 1.02 & 7.3 & 7.0 & 14.3 & 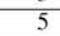 & & 10 & 1.43 & 0.82 & 1.67 & - & 0.51 \\
\hline G2WN-I2 & \multirow{3}{*}{$6 \times 12$} & \multirow{3}{*}{00} & \multirow{3}{*}{46.0} & \multirow{3}{*}{ 溶接 } & \multirow{3}{*}{ 無 } & L2 & 1.27 & 66.8 & 67.7 & 134.6 & 0 & 8 & 16 & 8.41 & 1.00 & 1.00 & - & 0.50 \\
\hline G2WN-I4 & & & & & & L2 & 1.24 & 71.3 & 76.3 & 147.6 & 13 & 14 & 27 & 5.47 & 0.65 & 1.69 & - & 0.52 \\
\hline G2WN-V2 & & & & & & L2 & 1.24 & 83.3 & 78.0 & 161.3 & 23 & 21 & 44 & 3.67 & 0.44 & 2.75 & - & 0.52 \\
\hline G2WR-12 & \multirow[b]{2}{*}{$300 \times 120 \times 6 \times 12$} & \multirow[b]{2}{*}{5.00} & \multirow[b]{2}{*}{46.0} & \multirow[b]{2}{*}{ 溶接 } & & F1 & 1.32 & 32.1 & 36.6 & 68.7 & 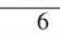 & 7 & 13 & 5.28 & 1.00 & 1.00 & - & 0.53 \\
\hline G2WR-I4 & & & & & & F2 & 1.40 & 75.3 & 87.6 & 162. & 13 & 14 & 27 & 6.03 & - & - & - & 0.54 \\
\hline G2BR-M0 & \multirow{4}{*}{$\mathrm{H}-300 \times 120 \times 6 \times 12$} & \multirow{4}{*}{5.00} & \multirow{4}{*}{46.0} & \multirow{4}{*}{ HTB } & & F1 & 1.30 & - & - & 11.2 & - & - & 1 & 11.20 & 3.10 & 0.18 & 1.00 & 1.00 \\
\hline G2BR & & & & & & F1 & 1.22 & 22.1 & 17.7 & 39 & 6 & 5 & 11 & 3.61 & 1.00 & 1.00 & 0.32 & 0.56 \\
\hline G2BR & & & & & 有 & F1 & 1.19 & 22.7 & 25.2 & 47. & 9 & 9 & 18 & 2.66 & 0.74 & 1.64 & 0.24 & 0.53 \\
\hline G2BR-V2 & & & & & & F1 & 1.25 & 23.8 & 25.9 & 49. & 7 & 7 & 14 & 3.56 & 0.98 & 1.27 & 0.32 & 0.52 \\
\hline G3BR-M0 & & & & & & F1 & 1.30 & - & - & 13. & - & - & 1 & 13.41 & - & - & 1.00 & 1.00 \\
\hline G3BR & & & & & & $\mathrm{F} 2$ & 1.31 & 49.5 & 47.9 & 97.4 & 8 & 8 & 16 & 6.08 & 1.00 & 1.00 & - & 0.51 \\
\hline G3BR-V1 & & & & & & F2 & 1.15 & 65.6 & 64.4 & 129. & 44 & 43 & 87 & 1.49 & 0.25 & 5.44 & - & 0.50 \\
\hline G3BR-RW & $\times 6 \times 16$ & 3.75 & 44.7 & HTB & 有 & F2 & 1.23 & 76.1 & 78.6 & 154.7 & 42 & 40 & 82 & 1.89 & 0.31 & 5.13 & - & 0.51 \\
\hline G3BR-RE & & & & & & F1 & 1.27 & 18.1 & 7.5 & 25 & 2 & 2 & 4 & 6.38 & - & - & 0.48 & 0.71 \\
\hline & & & & & & F1 & 1.23 & 23.4 & 22.8 & 46 & 9 & 9 & 18 & 2.57 & - & - & 0.19 & 0.51 \\
\hline & & & & & & L1 & 1.14 & - & - & 10 & - & - & 1 & 10.30 & 2.62 & 0.20 & 1.00 & 1.00 \\
\hline & & & & & & L1 & 1.19 & 18.5 & 20.8 & 39 & 5 & 5 & 10 & 3.93 & 1.00 & 1.00 & 0.38 & 0.53 \\
\hline G4WN-I4 & $\mathrm{H}-300 \times 120 \times 4.5 \times 12$ & 5.00 & 61.3 & 溶接 & 無 & L1 & 1.18 & 18.3 & 15.9 & 34 & 7 & 6 & 13 & 2.63 & 0.67 & 1.30 & 0.26 & 0.54 \\
\hline G4WN-V1 & & & & & & L1 & 1.19 & 33.3 & 33.6 & 66 & 22 & 21 & 43 & 1.56 & 0.40 & 4.30 & 0.15 & 0.50 \\
\hline G4WN-RW & & & & & & L1 & 1.20 & 31.8 & 30.5 & 62. & 31 & 29 & 60 & 1.04 & 0.26 & 6.00 & 0.10 & 0.51 \\
\hline G5WN-M0 & & & & & & L1 & 1.09 & - & - & 7. & - & - & 1 & 7.45 & 2.23 & 0.22 & 1.00 & 1.00 \\
\hline & $\mathrm{H}-350 \times 120 \times 4.5 \times 9$ & 6.67 & 73.8 & 溶接 & 無 & L1 & 1.13 & 17.2 & 12.9 & 30 & 5 & 4 & 9 & 3.34 & 1.00 & 1.00 & 0.45 & 0.57 \\
\hline G5WN-14 & & & & & & L1 & 1.14 & 21.7 & 19.5 & 41 & 8 & 7 & 15 & 2.75 & 0.82 & 1.67 & 0.37 & 0.53 \\
\hline G6WN-M0 & & & & & & L1 & 1.23 & - & - & 16 & - & - & 1 & 16.38 & 3.42 & 0.17 & 1.00 & 1.00 \\
\hline G6WN-12 & $\mathrm{H}-250 \times 120 \times 4.5 \times 9$ & 6.67 & 51.6 & 溶接 & 無 & $\mathrm{L} 1$ & 1.22 & 27.3 & 30.2 & 57.5 & 6 & 6 & 12 & 4.79 & 1.00 & 1.00 & 0.29 & 0.53 \\
\hline G6WN-14 & & & & & & $\mathrm{L} 1$ & 1.24 & 39.6 & 35.9 & 75.5 & 10 & 9 & 19 & 3.97 & 0.83 & 1.58 & 0.24 & 0.53 \\
\hline
\end{tabular}
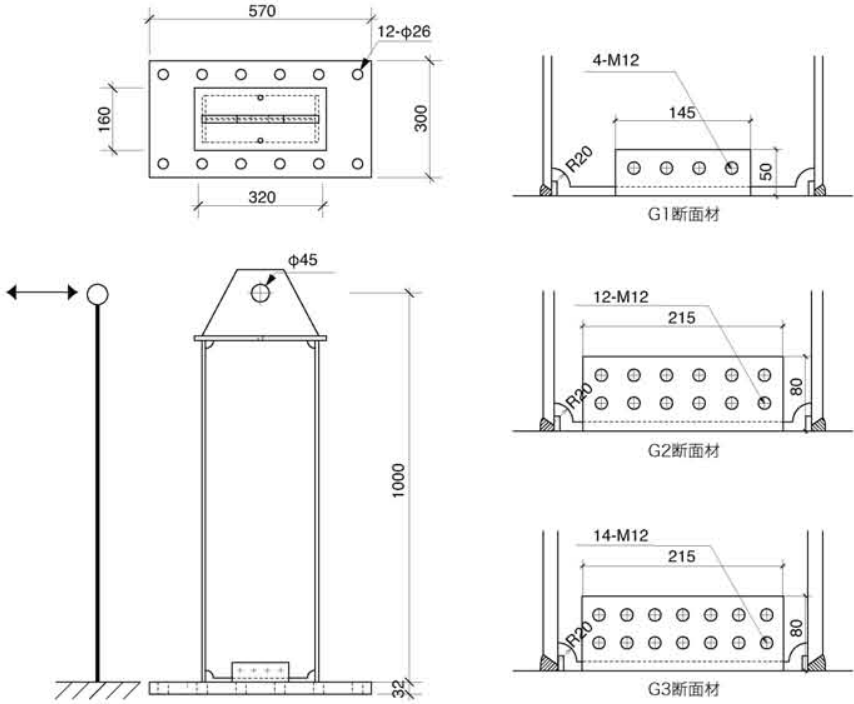

図 1 試験体形状

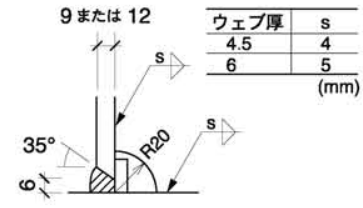

図 2 溶接部詳細

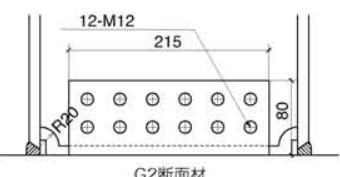

$\underline{8}$

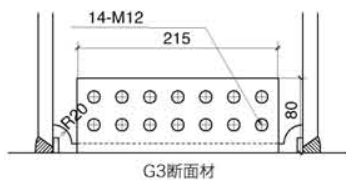

図 3 ウェブ HTB 接合部詳細
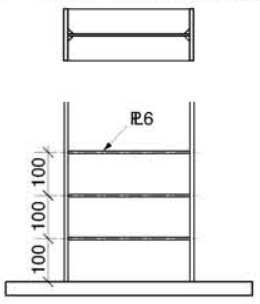

図 4 端部リブ補強

終端部に固形エンドタブを用いた。完全溶込み溶接, すみ肉溶接と も $\mathrm{CO}_{2}$ 半自動溶接法 (溶接ワイヤ YGW $11 \phi 1.2 \mathrm{~mm}$, 電流 $220 \mathrm{~A}$, 電 圧 $30 \mathrm{~V}$, 速度 $30 \sim 35 \mathrm{~cm} /$ 分) により行った. 溶接後の仕上げは行って いない.

ウェブ HTB 接合詳細を図 3 に示す.

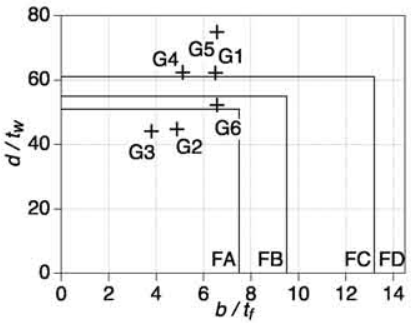

図 5 各梁断面の幅厚比と耐震規定による種別

一部の試験体には局部座屈を防止するためにリブ補強を行ってい る.リブ補強の詳細を図 4 に示す.

試験体一覧を表 1 に示す，試験体名称は以下のように定めている. 例 : G1WN-I2

1,2文字目: 断面形状を示す. G1 G6 の 6 種類の梁断面を 用いている。

3 文字目：ウェブ接合法を示す，溶接接合をW，HTB 接 合を Bで表す。

4 文字目：リブ補強の状態を示す，補強有りを R，無しを $\mathrm{N}$ で表す.

5,6 文字目: 載荷履歴を示す. 略称 MO, I 2 等 (2.3 参照) で 表す。

同一形状の試験体を試験体グループと称する，本実験は 9 グルー プから成り, 全試験体数は 30 である.

各梁断面の幅厚比を, 表 1 および耐震規定による梁部材種別によ る幅厚比制限と比較して図 5 に示す．既存の鋼構造高層建築におい ては現行の耐震規定の幅厚比制限を満たさない断面もしばしば用い

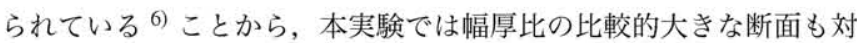
象としている.

\section{2 載荷方法}

試験体固定側のプレートをHTB を用いて反力治具に取付け, 先端 のピンジョイントを介して変位制御で準静的に載荷する，載荷部の 


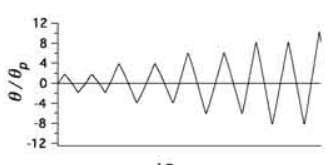

12

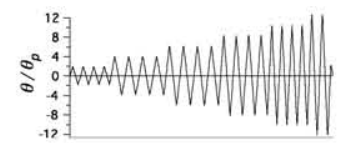

14

図 6 漸増繰返し㦲荷
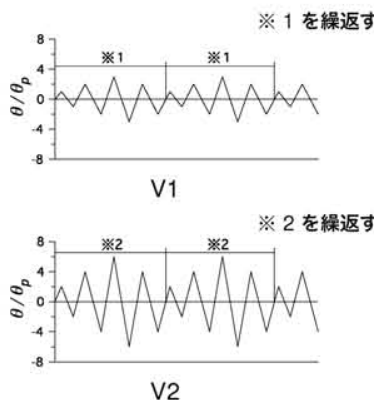

図 7 パターン繰返し蔵荷

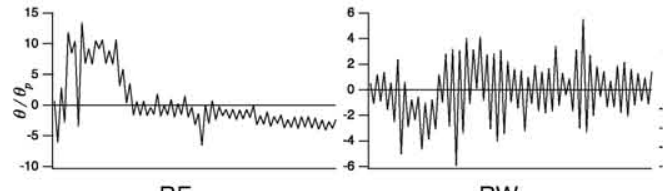

RE

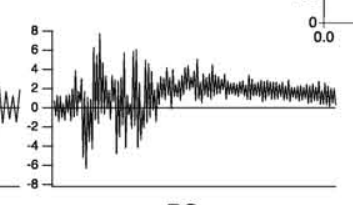

RS

図 8 ランダム成荷

面外変位は拘束されている. 充分な耐力低下に至った時点で載荷を 終了する。

\section{3 載荷履歴}

載荷履歴は次の 4 種類である. (括弧内は載荷履歴の略称)

\section{a. 単調載荷 $(\mathrm{MO})$ \\ b. 漸増繰返し載荷 $(12,14)$}

梁端のモーメントが全塑性モーメント $M_{p}$ に達したときの弾性変 形角 $\theta_{p}$ を基準とし, その偶数倍の振幅で繰返しつつ順次振幅を増加 させる. 同じ振幅で 2 回繰返す場合の略称を I2, 4 回繰返す場合の 略称を I4 とする (図 6). 既往の繰返し実験においては, I2 が標準的 に用いられている ${ }^{11)}$.

\section{c. パターン繰返し載荷 $(\mathrm{V} 1, \mathrm{~V} 2)$}

$\theta_{p}$ を基準としその倍数で増加減少するパターンを繰返す載荷であ る. $\theta_{p}$ の整数倍の振幅で最大 $3 \theta_{p}$ のパターンの場合を $\mathrm{V} 1, \theta_{p}$ の偶 数倍の振幅で最大 $6 \theta_{p}$ のパターンの場合を V2 とする. (図 7)

d. ランダム繰返し載荷 (RE, RW, RS)

梁降伏型骨組モデルに地震波を入力したときの梁応答に基づき定 めたランダムな繰返し載荷注1) である. (図 8)

\section{3 実験結果}

\section{1 短柱圧縮試験}

短柱圧縮試験の目的の一つは局部座屈で決まる最大圧縮応力度の 把握である．曲げを受ける場合と一様な圧縮力を受ける場合の垂直 応力度分布の違いにより, 梁の圧縮側最大応力度は短柱圧縮試験に よる最大応力度を上回ることが知られている 12),13). 両者の最大応 力度が概ね対応することを目指して, 本実験においては各梁試験体 の断面せいを $1 / 2$ とした断面を用いて短柱圧縮試験を行った。 ただ し, G3 断面試験体については, 全試験体共リブ補強 (図 4) を行って いるので，梁試験体と同一断面でリブ補強を行った試験体を用いて 短柱圧縮試験を行った。試験体長さは, 全試験体共断面幅の 3 倍と した.

試験より得られた応力歪関係を図 9 に示す。G3 断面以外は梁試 験体断面成を $1 / 2$ とした断面を用いているので，短柱試験体名に／を 付けて示した. また, 短柱圧縮試験結果から求めた降伏応力度 $\left(\sigma_{y}\right)$,
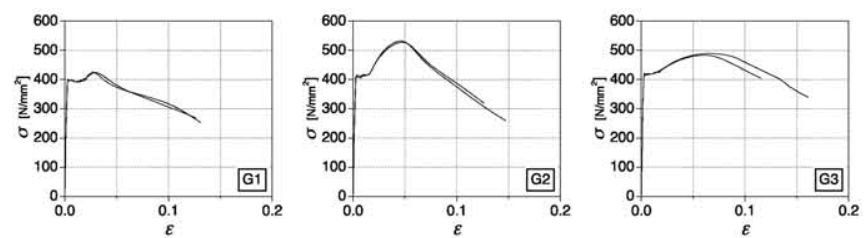

G1'

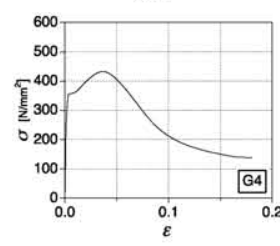

G4'
G2'

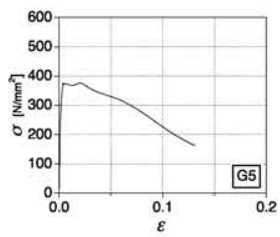

G5
G3

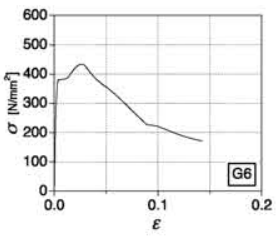

G6

図 9 短柱圧縮試験結果

表 3 リブ補強を有する武験体の崩壊性状

\begin{tabular}{|c|c|c|c|}
\hline 試験体名 & フラ゙龟裂起点 & 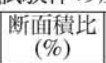 & 崩壊 \\
\hline G1BR-I2 & 中央 & 79 & F1 \\
\hline G1BR-I4 & 中央 & 87 & F1 \\
\hline G2BR-MO & 中央 & 86 & F1 \\
\hline G2BR-I2 & 中央 & 81 & F1 \\
\hline G2BR-I4 & 中央 & 68 & $\mathrm{~F} 1$ \\
\hline G2BR-V2 & 中央 & 92 & F1 \\
\hline G2WR-I2 & 中央 & 82 & F1 \\
\hline G2WR-I4 & 端部 & 96 & F2 \\
\hline G3BR-MO & 中央 & 74 & F1 \\
\hline G3BR-I2 & 端部 & 91 & $\mathrm{~F} 2$ \\
\hline G3BR-V1 & 端部中央同時 & 96 & $\mathrm{~F} 2$ \\
\hline G3BR-RW & 端部 & 93 & $\mathrm{~F} 2$ \\
\hline G3BR-RE & 端部中央同時 & 90 & F1 \\
\hline G3BR-RS & 中央 & 82 & $\mathrm{~F} 1$ \\
\hline
\end{tabular}

最大応力度 $\left(\sigma_{B}\right)$ および応力上昇率 $\left(\sigma_{B} / \sigma_{y}\right)$ を表 2 に示す.

\section{2 梁試験体の荷重変形関係}

各梁試験体について，変位載荷履歴および実験で得られた荷重変 形関係を図 10 に示す. 図中において，以下の記号を用いた.

$M$ : 固定端モーメント, $M_{p}$ : 全塑性モーメント, $\theta$ : 部材角,

$\theta_{p}: M$ が $M_{p}$ に達したときの弾性部材角

なお， $M_{p}$ は表 2 の $\sigma_{y}$ を用いて算出した.

\section{4 塑性挙動に関する考察}

\section{1 最大耐力決定要因と崩壊モード}

各試験体の最大耐力決定要因は，リブ補強の有無により以下のよ うであつた。

\section{a) リブ補強無しの試験体}

全試験体において局部座屈により最大耐力が決定した。ただし， 次の 2 種類の崩壊性状が見られた.

崩壊性状 1 (L1)：フランジ破断を生じることなく載荷の進行に伴 い耐力が充分に低下した。(試験体グループ G1WN, G4WN, G5WN，G6WN が該当)

崩壊性状 2 (L2)：最大耐力に達した後フランジに亀裂が発生し，フ ランジが破断した。(試験体グループ G2WN が該当)

上記崩壊性状 1 の場合を崩壊モード L1，崩壊性状 2 の場合を崩壊 モードL2, 両者を併せて局部座屈崩壊と称する.

\section{b) リブ補強有りの試験体}

全試験体においてフランジ破断により最大耐力が決定した。 ただ し，次の 2 種類の破断性状が見られた.

破断性状 $1(F 1)$ : フランジ溶接部中央から亀裂が発生し，フランジ 

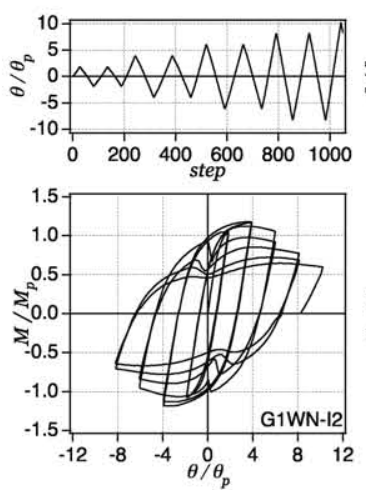

(1) G1WN-12
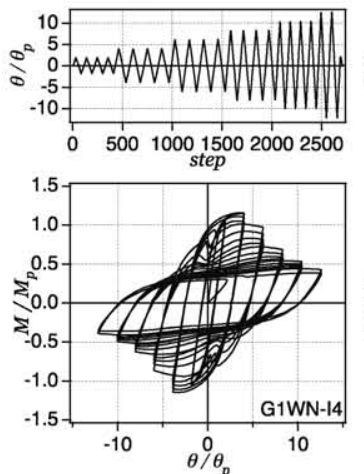

(2) G1WN-14
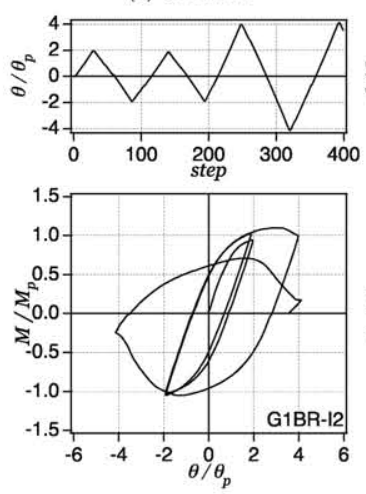

(3) G1BR-12
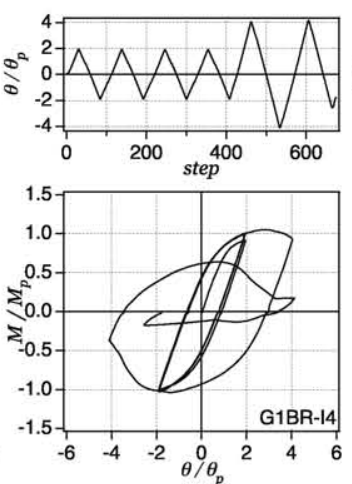

(4) G1BR-14
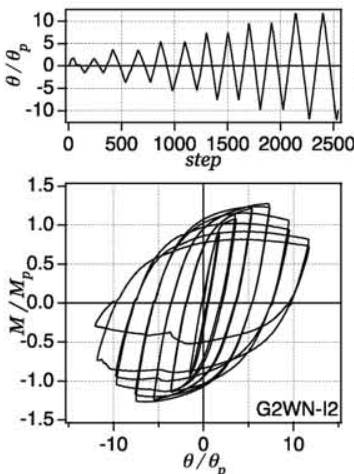

(5) G2WN-12
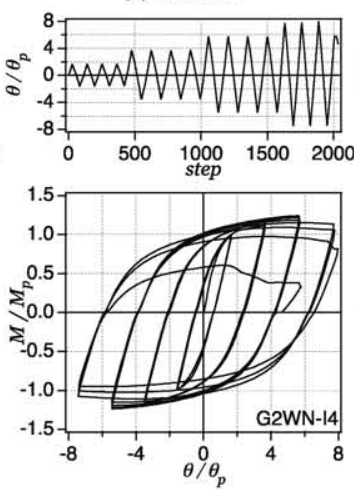

(6) G2WN-14

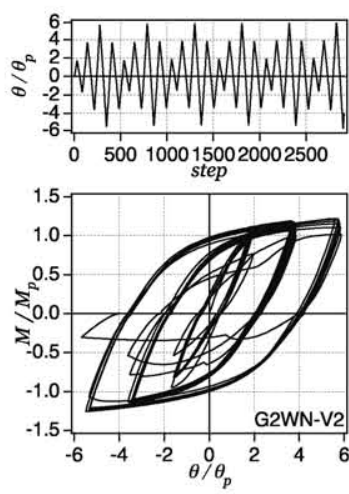

(7) G2WN-V2
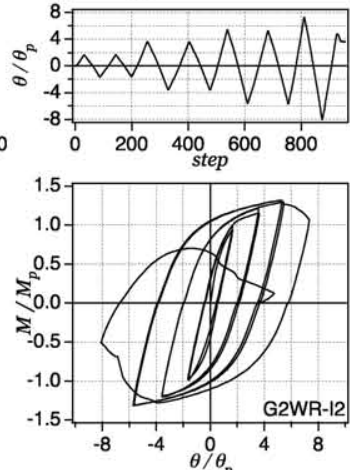

(8) G2WR-12
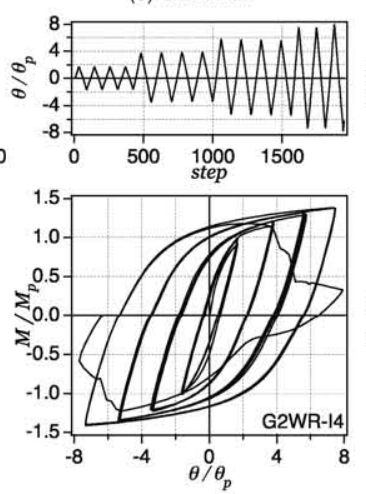

(9) G2WR-14
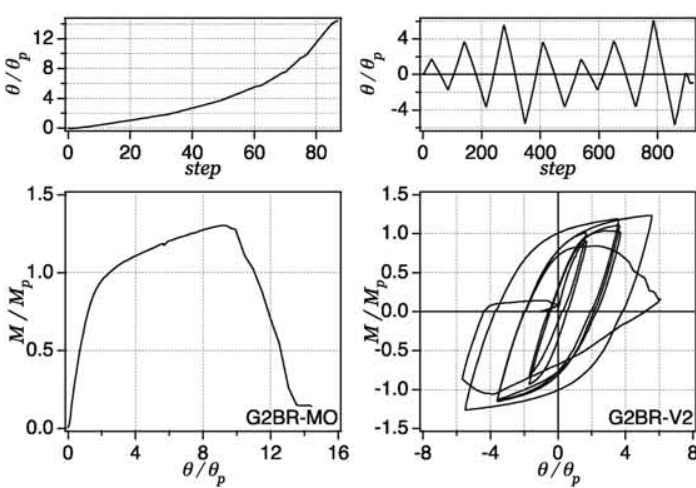

(10) G2BR-MO
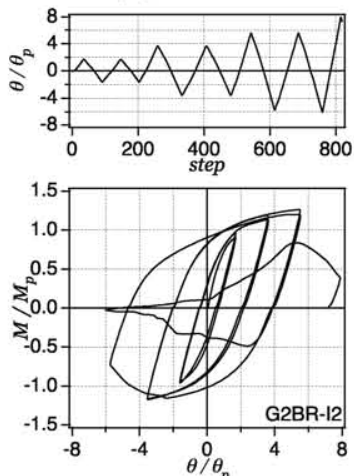

(11) G2BR-12
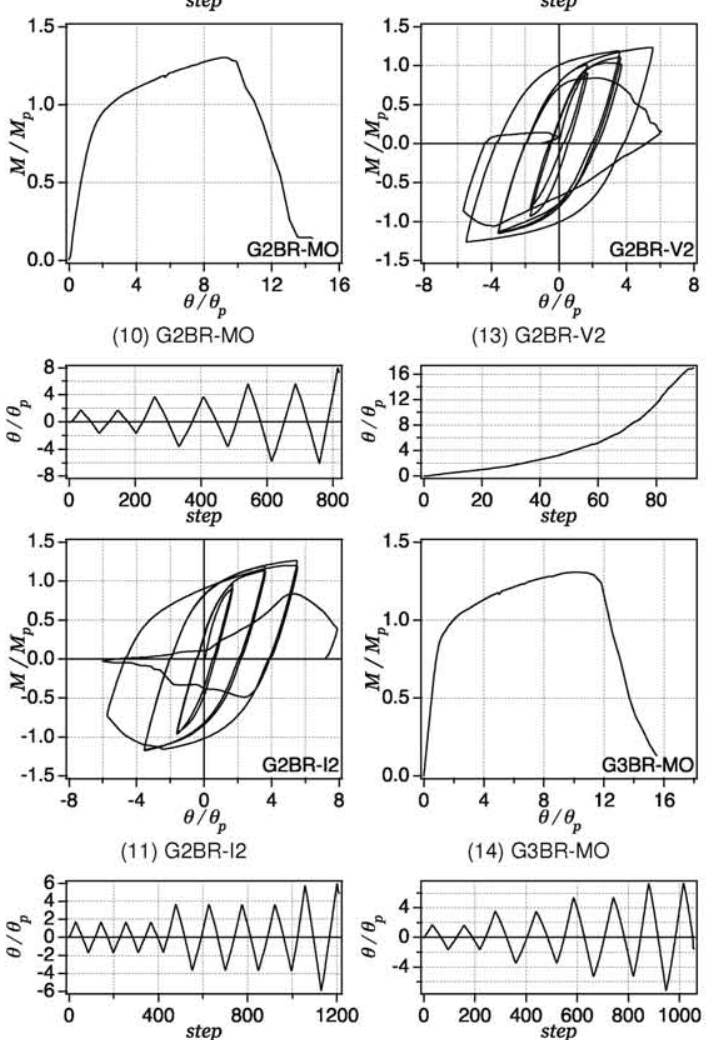

(13) G2BR-V2
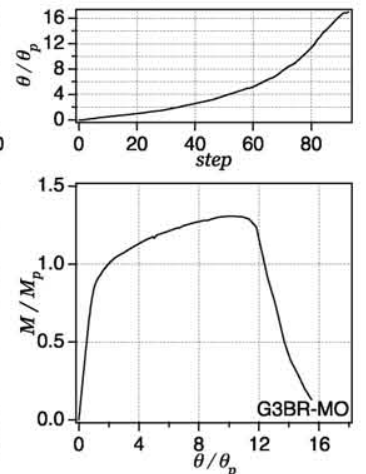

(14) G3BR-MO

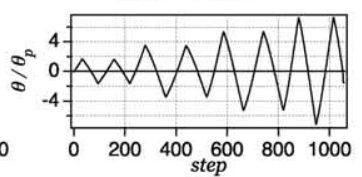

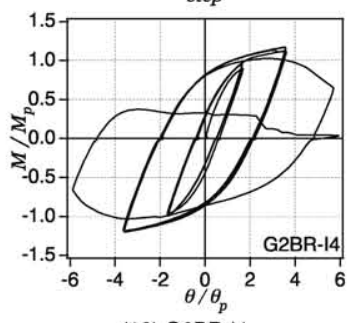

(12) G2BR-14

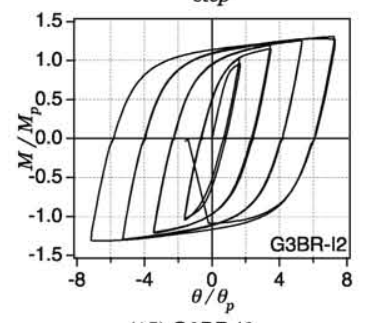

(15) G3BR-12

図 10 截荷履歴と荷重変形関係

全断面破断に至った．破断後の断面積比 (破断後フランジ断面積 と載荷前フランジ断面積の比) は 70\% 90\% 程度であった.

破断性状2 (F2)：フランジ溶接部端部から亀裂が発生し, フランジ 全断面破断に至った．断面積比は 90 95\% 程度であった.

上記破断性状 1 の場合を崩壊モード F1, 破断性状 2 の場合を崩壊 モード F2, 両者を併せて破断崩壊と称する.

各試験体のフランジ龟裂開始位置, 断面積比および崩壊モードを 表 3 に示す. G3BR-V1 および G3BR-RE 試験体のフランジ亀裂開 始位置は端部と中央同時であったが, 断面積比の值に基づき前者を 崩壊モード F2, 後者を崩壊モードF1 とした. 試験グループ G2WR, G3BR については同一グループで 2 種類の崩壊モードが生じたが, 同一グループ試験体について載荷前試験体外観に特に違いは見られ ず, 異なる崩壊モードが生じた要因は不明である，崩壊モード F2 試 験体の方が, 崩壊モード F1 試験体に比べてエネルギー吸収能力が高 い傾向を示している.
各試験体の崩壊モードを表 1 に示した.

\section{2 耐力上昇率}

耐力上昇率 $\alpha$ を次式で定義する.

$\alpha=\frac{M_{\max }}{M_{p}}$

ここで, $M_{\max }:$ 最大曲げ耐力

実験結果より得られた各試験体の $\alpha$ の值を表 1 に示す.

以下に耐力上昇率 $\alpha$ についての考察を述べる.

\section{a) 局部座屈崩壊の場合}

短柱圧縮試験による応力上昇率 $\left(\sigma_{B} / \sigma_{y}\right)$ と $\alpha$ の関係を図 11 に示 す. 単調載荷の場合を○で, 繰返し載荷の場合を・で表示している. 図 11 より同一形状の試験体において, 単調載荷時の $\alpha$ は繰返し載 荷時の $\alpha$ と比較して同等または小さいことが分かる.

本実験においては $\sigma_{B} / \sigma_{y}$ と $\alpha$ の下限值の間にほぼ次の関係がみ られた。

$$
\alpha=0.33 \frac{\sigma_{B}}{\sigma_{y}}+0.77
$$




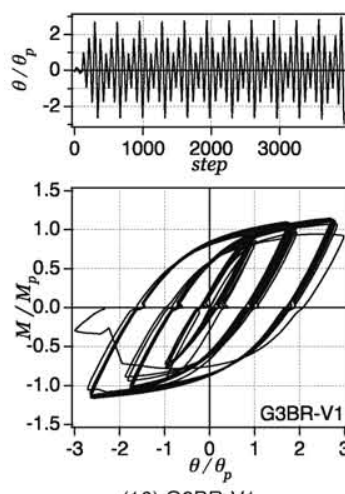

(16) G3BR-V1
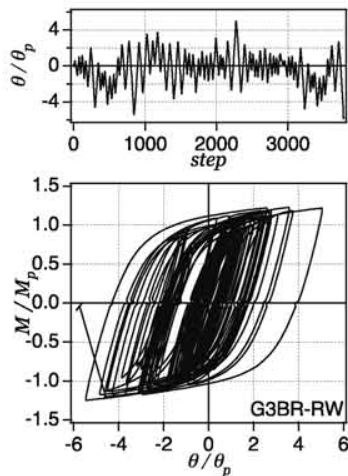

(17) G3BR-RW
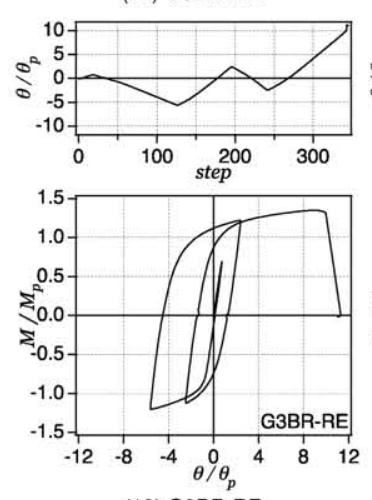

(18) G3BR-RE
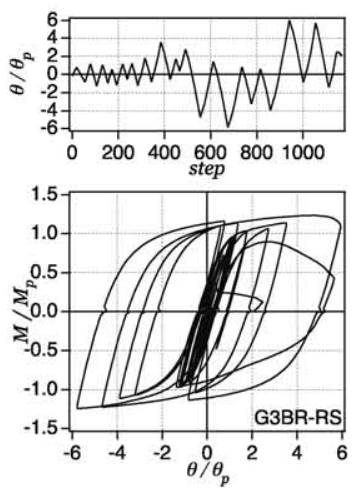

(19) G3BR-RS
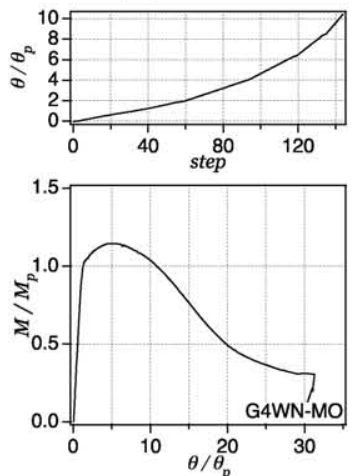

(20) G4WN-MO
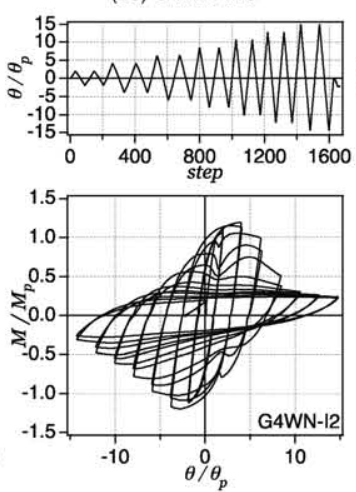

(21) G4WN-12
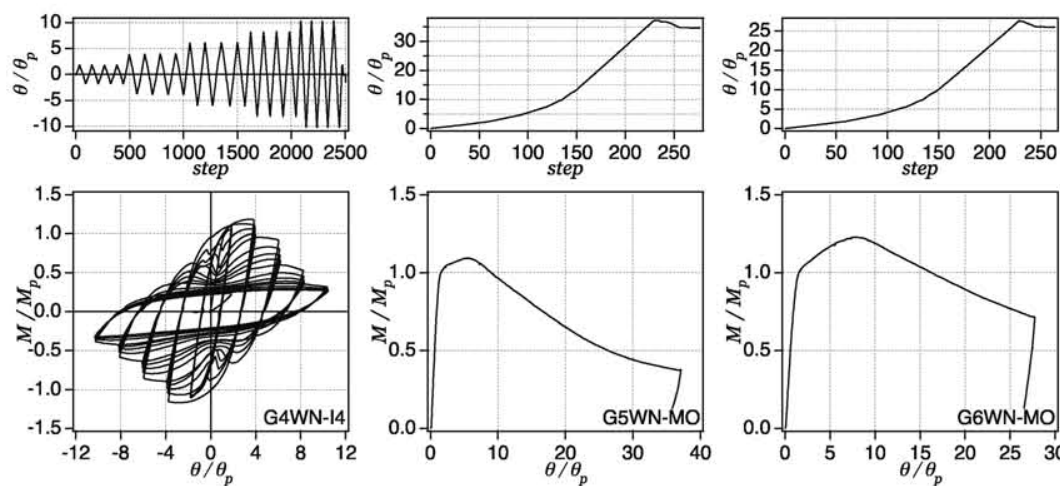

(22) G4WN-14

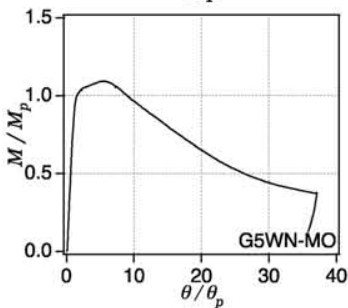

(25) G5WN-MO
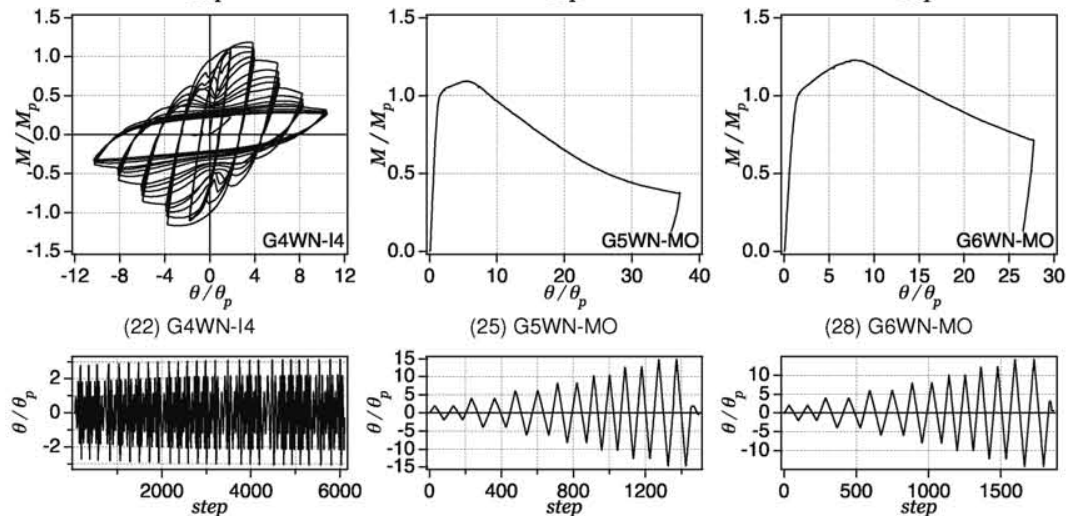

(28) G6WN-MO
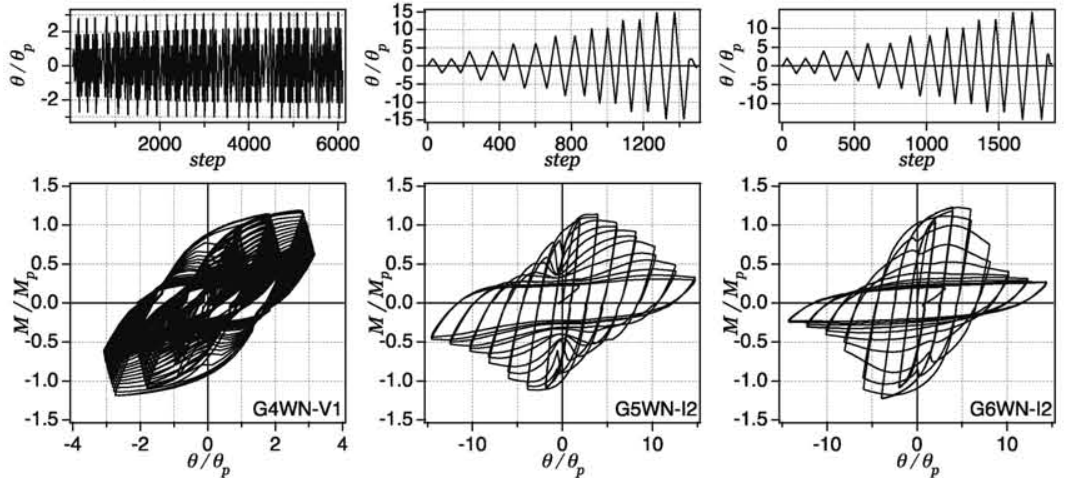

(23) G4WN-V
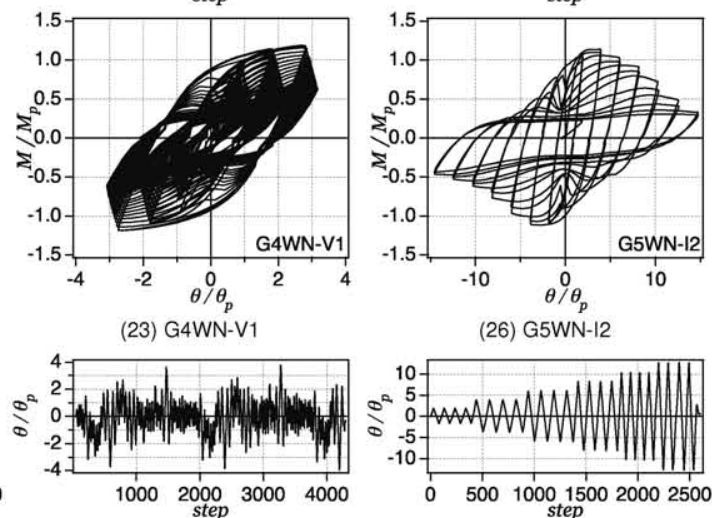

(26) G5WN-12

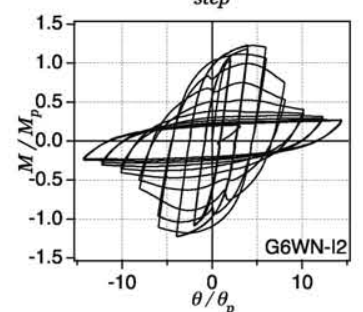

(29) G6WN-12
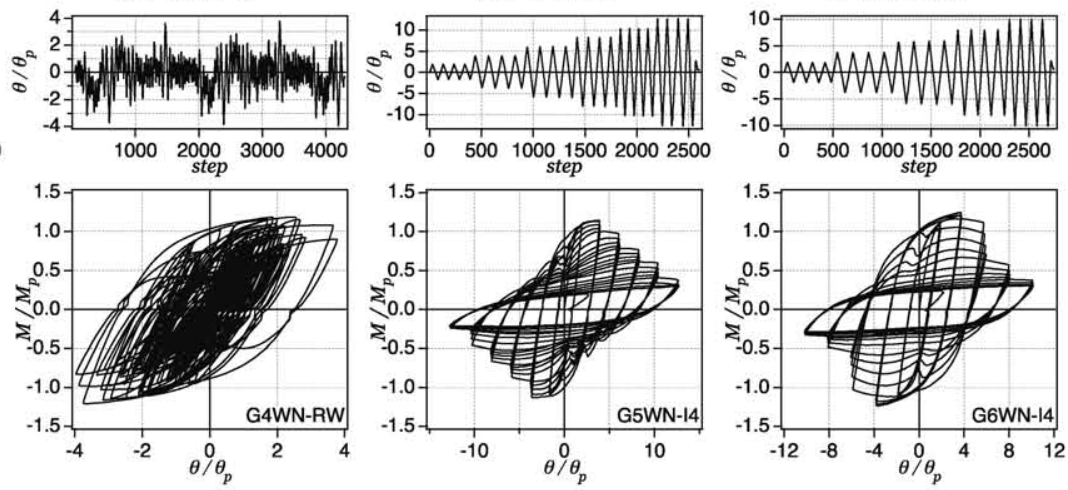

(24) G4WN-RW

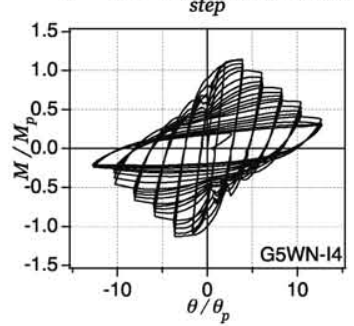

(27) G5WN-14

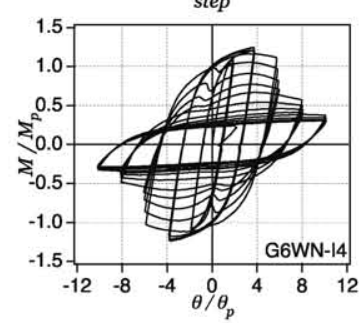

(30) G6WN-14

図 10 載荷履歴と荷重変形関係 (つづき)

式 (2) を図中に破線で示す. 式 (2)の適用性について検討するために は今後のデータの蓄積が必要である.

耐力上昇率について, 文献 3) による評価值と実験結果の関係を 図 12 に示す。評価值は実験結果のほぼ限となっており, 評価法は 妥当であると考えられる.

b) 破断崩壊の場合

耐力上昇率について, 文献 14)，15）による評価值と実験結果の関 係を図 13 に示す，G1BR グループを除いて評価值は実駼結果のほぼ 下限に対応している.

\section{3 単調載荷曲線とスケルトン曲線の比較}

単調載荷実験を行っている試験体グループについて, 最大荷重に 達するまでのスケルトン曲線 (破線) を単調載荷曲線 (実線) と比較し て図 14 に示す. (a) は局部座屈崩壊の場合, (b) は破断崩壊の場合で ある。

最大荷重に達するまでのスケルトン曲線について, 次の特徵が見
られる.

局部座屈崩壊の場合：載荷履歴によりスケルトン曲線がやや異な る. スケルトン曲線は単調載荷曲線に比べ塑性剛性が若干上昇 する傾向がみられる。

破断崩壊の場合：異なる載荷履歷の場合のスケルトン曲線および単 調載荷曲線はよく一致している.

\section{5 エネルギー吸収能力に関する考察}

\section{1 安定限界}

一般に破断崩壊の場合は最大耐力に達した後のエネルギー吸収量 は少ない, 一方, 局部座屈崩壊の場合は最大耐力に達した後も徐々 に耐力を低下させながら個材としては塑性エネルギー吸収を行うこ とが出来る. しかし, 多層骨組における梁材の性能として考えると, 部材が最大耐力以降の劣化域に入ると劣化部材への損傷集中の度 合いが著しくなり, 骨組全体の地震エネルギー吸収への寄与が困難 


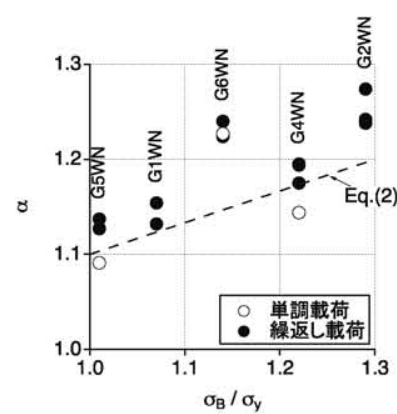

図 11 短柱圧縮試験結果による $\sigma_{B} / \sigma_{y}$ と梁の 耐力上昇率 $\left(\alpha=M_{\max } / M_{p}\right)$ の関係
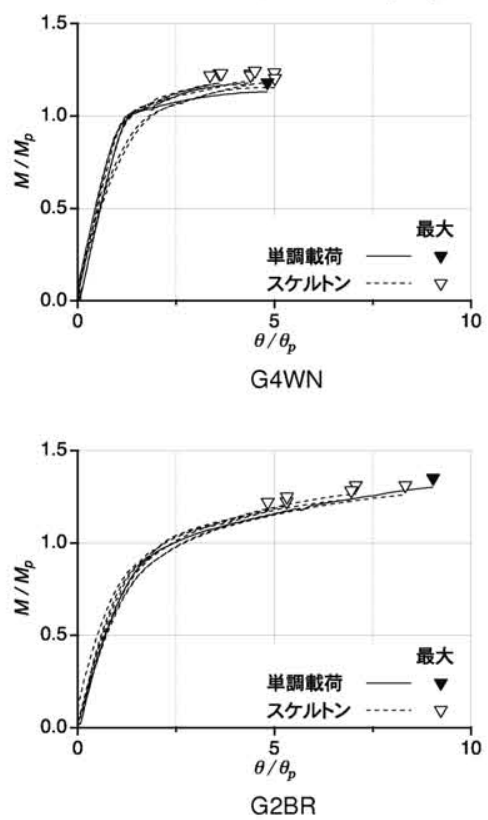

(b) 破断崩壊の場合

図 14 単調载荷曲線とスケルトン曲線の比較

である．そこで本研究では最大耐力に達した後全塑性モーメントに 至ったときを安定限界とし, 安定限界に至るまでに吸収するエネル ギーを部材のエネルギー吸収能力として評価する.

\section{2 有効吸収エネルギーと有効半サイクル数}

塑性吸収エネルギーの大きさは次式による無次元量 $\eta$ で表す。

$$
\begin{aligned}
& \eta=\frac{W_{p}}{M_{p} \theta_{p}} \\
& W_{p}: \text { 塑性吸収エネルギー量 }
\end{aligned}
$$

端部モーメントの值がゼロから次のゼロに至るまでを半サイク ルとし，半サイクルで吸収するエネルギーを半サイクル吸収エネル ギーとする (図 15).

例として, 試験体 G3BR-RS について正側および負側で吸収する 半サイクルエネルギーの分布を図 16 に示す.

半サイクル吸収エネルギーのうち，次の条件を満たすものを有効 半サイクル吸収エネルギーとする.

・安定限界に至る迄であること.

・半サイクル吸収エネルギーの最大值の $5 \%$ 以上の大きさである こと.

正側における有効半サイクル吸収エネルギーの和およびその半サ イクル数を $\eta_{e}^{+}, N_{e}^{+}$, 負側におけるそれらを $\eta_{e}^{-}, N_{e}^{-}$で表す.

また, 次式による $\eta_{e}, N_{e}, \overline{\Delta \eta}_{e}$ をそれぞれ有効吸収エネルギー,

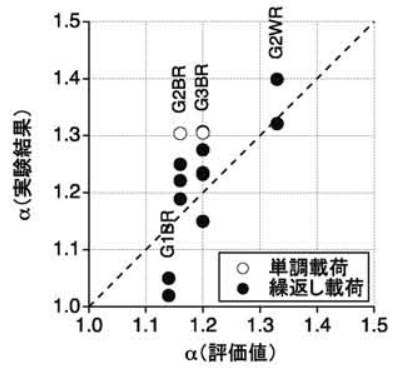

図 13 梁の耐力上昇率について文献 14,15) に よる評価值と実験結果の関係

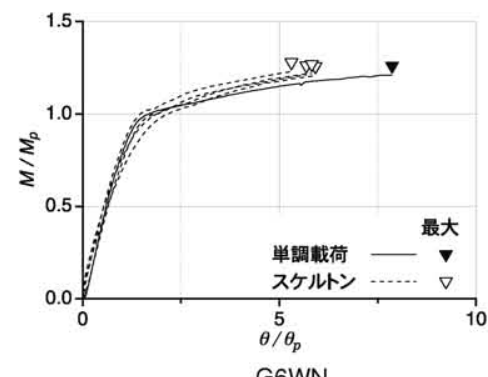

G6WN

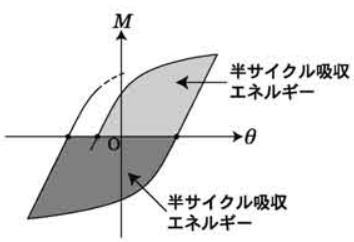

図 15 半サイクル吸収エネルギー G3BR

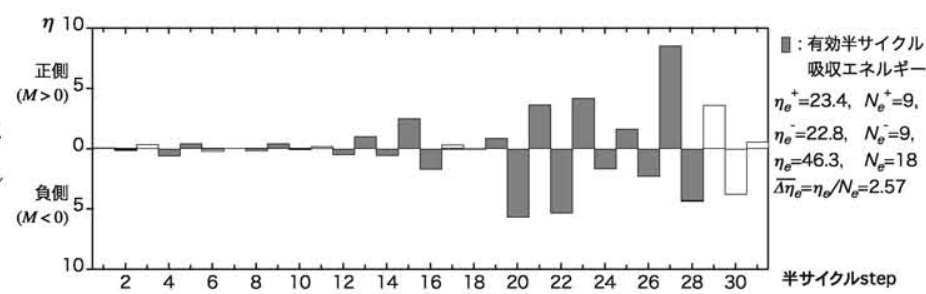

図 16 半サイクル吸収エネルギーの分布 (G3BR-RS)

有効半サイクル数, 平均エネルギー振幅とする.

$$
\begin{aligned}
\eta_{e} & =\eta_{e}^{+}+\eta_{e}^{-} \\
N_{e} & =N_{e}^{+}+N_{e}^{-} \\
\overline{\Delta \eta_{e}} & =\frac{\eta_{e}}{N_{e}}
\end{aligned}
$$

表 1 に各試験体の $\eta_{e}^{+}, \eta_{e}^{-}, \eta_{e}, N_{e}^{+}, N_{e}^{-}, N_{e}, \overline{\Delta \eta}_{e}$ を示す.

5.3 平均エネルギー振幅 $\left(\overline{\Delta \eta}_{e}\right)$ と有効半サイクル数 $\left(N_{e}\right)$ の関係 1) 漸増繰返し載荷 12 を基準とする場合

多くの既往の実験において漸増繰返し載荷 I2(図 6) が標準的な載 荷履歴として用いられており, 本実験においてもすべての試験体グ ループにおいて I2 載荷を行っている. I 2 載荷の場合のエネルギー吸 収性能を基準として実験結果を整理する.

I2 載荷の場合の $\overline{\Delta \eta}_{e}$ および $N_{e}$ をそれぞれ $\overline{\Delta \eta}_{I}, N_{I}$ とし，各試 験体について $\overline{\Delta \eta}_{e}$ および $N_{e}$ を同一グループの $\overline{\Delta \eta}_{I}, N_{I}$ で除した 


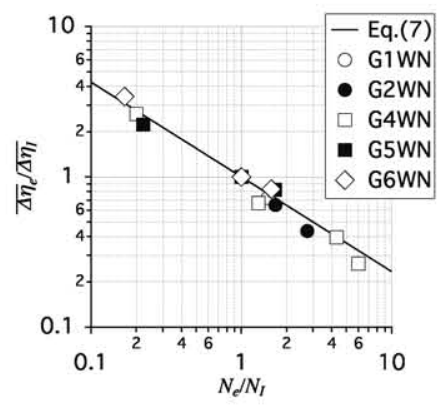

(a) 局部座屈崩壊

図 $17 \overline{\Delta \eta}_{e} / \overline{\Delta \eta}_{I}$ と $N_{e} / N_{I}$ の関係

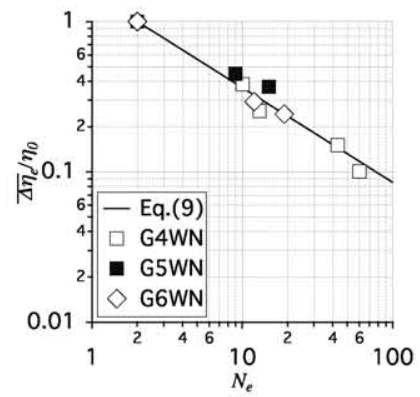

(a) 局部座屈崩壊

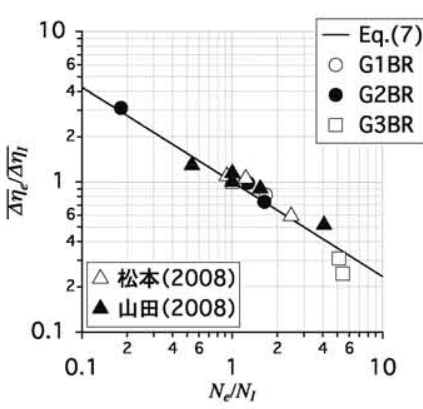

(b) 破断崩壊

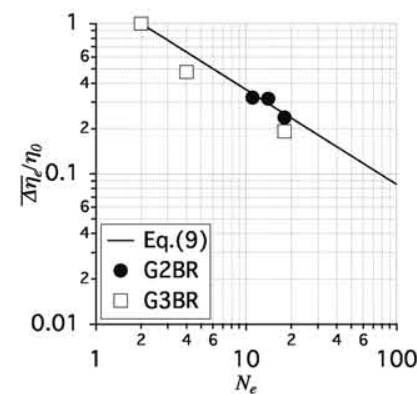

(b) 破断崩壊
図 $18 \quad \overline{\Delta \eta}_{e} / \eta_{0}$ と $N_{e}$ の関係

值を表 1 に示す。ここで, 単調載荷試験体については, 安定限界直 前の状態から負側方向に載荷すれば正側で吸収した歪エネルギーと 同程度のエネルギーを負側で安定限界に至るまでに吸収できると仮 定し, $N_{e}$ を 2 として $N_{e} / N_{I}$ の值を算出した. ただし, 各試験体グ ループにおいて I2 載荷試験体と同一の崩壊モードとなった試験体の みを対象とした。

$\overline{\Delta \eta}_{e} / \overline{\Delta \eta}_{I}$ と $N_{e} / N_{I}$ の関係を図 17 に示す. 両対数軸のグラフ上 で両者はほぼ直線関係にあり, 局部座屈崩壊と破断崩壊の場合共に, 図中に実線で示す次式で近似できる.

$$
\frac{\overline{\Delta \eta}_{e}}{\overline{\Delta \eta_{I}}}=\left(\frac{N_{e}}{N_{I}}\right)
$$

\section{2) 単調載荷 $M O$ を基準とする場合}

単調載荷試験を行っている試験体グループについて, 単調載荷時 の $\eta_{e}$ を $\eta_{0}$ とし, $\overline{\Delta \eta}_{e}$ を同一グループの $\eta_{0}$ で除した值を表 1 に示 す．ただし，試験体グループ G3BR については載荷履歴 MO と同 一の崩壊モード (F1) を示した試験体 (G3BR-RE, RS) のみを対象と した.

$\overline{\Delta \eta}_{e} / \eta_{0}$ と $N_{e}$ の関係を図 18 に示す.ここで, 前述と同様の理由 により単調載荷試験結果は $N_{e}$ を 2 としてプロットした.

ここで, 式 (7) が単調載荷時にも成り立つと考え, 式 (7)の $\overline{\Delta \eta}_{e}$, $N_{e}$ に単調載荷の值 $\eta_{0}, 2$ を代入すると,

$$
\frac{\eta_{0}}{\overline{\Delta \eta}_{I}}=\left(\frac{2}{N_{I}}\right)
$$

式 (7), (8) より $\overline{\Delta \eta}_{I}, N_{I}$ を消去すれば, 単調載荷時のエネルギー吸 収量を基準としたときの平均エネルギー振幅と有効繰返し数の関係 を表す次式が得られる。

$$
\frac{\overline{\Delta \eta}_{e}}{\eta_{0}}=1.55 N_{e}^{-0.63}
$$

式 (9)の関係を図 18 に実線で示す。実験結果と実線は対応して いる.

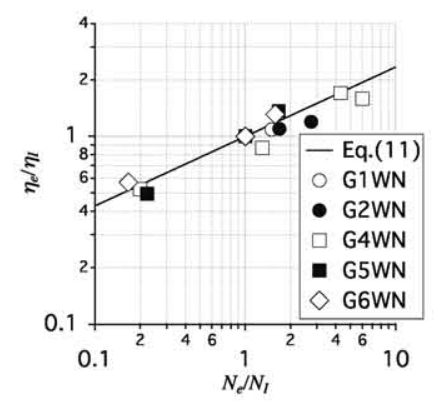

(a) 局部座屈崩填

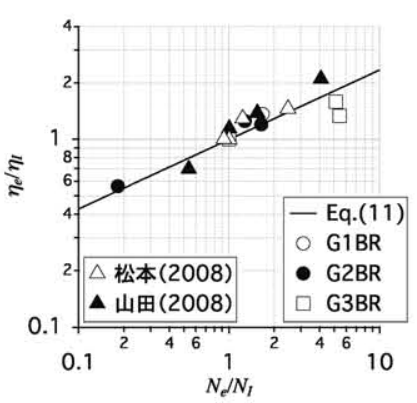

(b) 破断崩壊
図 $19 N_{e} / N_{I}$ と $\eta_{e} / \eta_{I}$ の関係

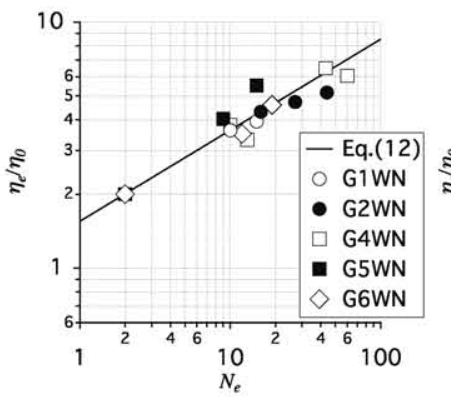

(a) 局部座屈崩壊

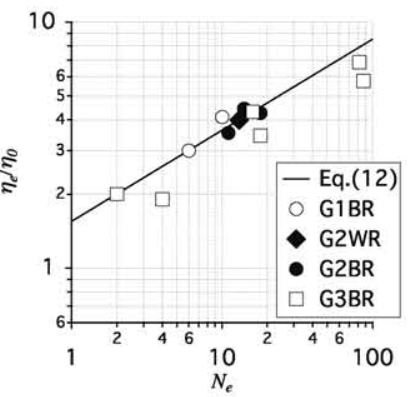

(b) 破断崩壊
図20 $N_{e}$ と $\eta_{e} / \eta_{0}$ の関係

\section{4 有効吸収エネルギー $\eta_{e}$ の推定}

I2 載荷時の $\eta_{e}$ を $\eta_{I}$ とすれば,

$$
\overline{\Delta \eta}_{I}=\frac{\eta_{I}}{N_{I}}
$$

である.

式 (6), (7), (10)より $\overline{\Delta \eta}_{e}, \overline{\Delta \eta}_{I}$ を消去すれば次式が得られる. $\frac{\eta_{e}}{\eta_{I}}=\left(\frac{N_{e}}{N_{I}}\right)^{0.37}$

式 (6)，(9) より $\overline{\Delta \eta}_{e}$ を消去すれば次式が得られる.

$\frac{\eta_{e}}{\eta_{0}}=1.55 N_{e}^{0.37}$

式 (11) は I2 載荷時の吸収エネルギーに基づき, 式 (12) は単調載 荷時の吸収エネルギーに基づき，任意の繰返し載荷時の吸収エネル ギーを推定する式である.

式 (11) と実験結果の関係を図 19 に示す.

ここで, 式 (11), (12)より, I2 載荷時の吸収エネルギー $\eta_{I}$ と単調 載荷時の吸収エネルギー $\eta_{0}$ の関係を表す次式が得られる.

$$
\eta_{0}=0.65 \eta_{I} N_{I}^{-0.37}
$$

単調載荷試験を行っていない試験体グループについては式 (13) を 用いて $\eta_{0}$ を推定し, 全試験体グループについて式 (12) と実験結果 の関係を図 20 に示す.

図 19，20において，5.31) に述べた仮定により単調載荷時の值は $N_{e}$ を $2, \eta_{e}$ を $2 \eta_{0}$ をとしてプロットしている. 実験結果と提案式 は対応していることが分かる，式 (11), (12) は局部座屈崩壊型, 破 断崩壊型いずれの場合についても適用可能な式であり。これらの式 により繰返し載荷時のエネルギー吸収能力を推定することができる. エネルギー吸収を限界づける要因の異なる局部座屈崩壊型と破断崩 壊型に対して同一の関係式が成立つことは興味深いが，その理由に ついての考察は今後の課題とする。

提案する推定式は設計における部材性能検討に利用することがで きると思われる注2). 


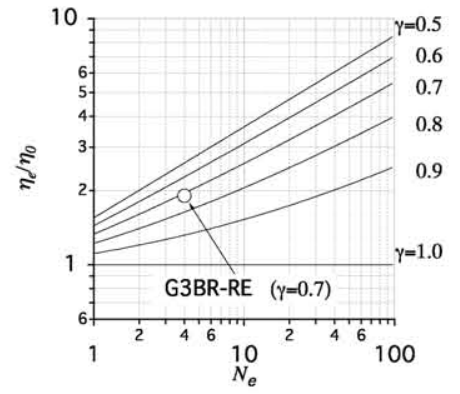

図 21 エネルギーの庐りの影響

式 (11), (12) はエネルギー吸収が正負両側でほぼ均等になされた 実験結果に基づいて導かれており，エネルギー吸収の偏りが小さい 場合に適用されるものである.

次に，エネルギー振幅の正負いずれかへの偏りが $\eta_{e}$ に及ぼす影響 について考察する.

\section{5 エネルギー振幅の偏りの影響}

次式による $\gamma$ をエネルギーの偏りの指標とする.

$$
\gamma=\frac{\max \left(\eta_{e}^{+}, \eta_{e}^{-}\right)}{\eta_{e}^{+}+\eta_{e}^{-}}
$$

$\gamma$ の值は均等振幅のとき 0.5 , 完全に偏るとき 1.0 である.

各試験体について $\gamma$ の值を表 1 に示す. 本実験において, 繰返し 載荷試験体の $\gamma$ は G3BR-RE を除いて 0.5 に近い.

式 (11), (12)は $\gamma=0.5$ のとき成立つ式と考えられる.

$\gamma=1.0$ のときは塑性変形が片側に進行するので $\eta_{e}$ は $\eta_{0}$ に等 Lく

$$
\frac{\eta_{e}}{\eta_{0}}=1.0
$$

である.

$0.5<\gamma<1.0$ に対しては式 (12) と (15) との線形補間により $\frac{\eta_{e}}{\eta_{0}}$ を評価すると仮定すれば,

$\frac{\eta_{e}}{\eta_{0}}=1.55 N_{e}^{0.37}-(2 \gamma-1)\left(1.55 N e^{0.37}-1\right)$

より, 次式が得られる.

$\frac{\eta_{e}}{\eta_{0}}=3.1(1-\gamma) N_{e}^{0.37}+2 \gamma-1$

式 (13)，(16)より $\eta_{0}$ を消去すれば次式が得られる.

$$
\frac{\eta_{e}}{\eta_{I}}=2(1-\gamma)\left(\frac{N_{e}}{N_{I}}\right)^{0.37}+0.65(2 \gamma-1) N_{I}^{-0.37}
$$

エネルギー振幅の偏りを考慮する場合は，式 (11)，(12)の代りに 式 (17), (16) を用いてエネルギー吸収能力を推定する.

式 (16) の関係を図 21 に実線で示す. 同図中に G3BR-RE $(\gamma=$ 0.7)の結果をプロットしている. 実験結果は式 (16) と対応して いる.

本実験ではエネルギーの偏りを有するデータが少ないため, 式 (16), (17) の適用性については今後実験により検証する必要が ある.

\section{6 既往の文献における実験結果}

文献 9)，10) の研究において, 同一形状の試験体を用い載荷履歷を 変数として実験が行われている. 載荷履歴および実駼結果を表 4 に 示す。エネルギー吸収量および繰返し数について, 漸増繰返し載荷 I2 の結果を基準として整理している，なお，すべての試験体が端部

\begin{tabular}{|c|c|c|c|c|c|c|c|}
\hline 文献 & 武験体 & 戎荷復歷 & $N_{e}$ & $\eta$ & $\overline{\Delta \eta}_{e}$ & $\frac{N_{c}}{N_{I}}$ & $\frac{\overline{\Delta \eta_{c}}}{\eta_{I}}$ \\
\hline \multirow[t]{4}{*}{ 9) } & No.1 & 漸増振幅 (I2) & 13 & 37.5 & 2.88 & $\frac{N 1}{1.00}$ & 1.00 \\
\hline & No.2 & 2 段振幅 $\left( \pm 2 \theta_{p}, \pm 3 \theta_{p}\right)$ & 32 & 54.8 & 1.71 & 2.46 & 0.59 \\
\hline & No.3 & 交番振幅 $\left(+6 \theta_{p},-2 \theta_{p}\right)$ & 12 & 37.8 & 3.15 & 0.92 & 1.09 \\
\hline & No.4 & 一定振幅 $\left( \pm 4 \theta_{p}\right)$ & 16 & 48.6 & 3.04 & 1.23 & 1.05 \\
\hline \multirow[t]{5}{*}{ 10) } & 1 & 漸増振幅（I2） & 13 & 69.3 & 5.33 & 1.00 & 1.00 \\
\hline & 2 & 漸減振幅（I2 の逆進行） & 13 & 79.1 & 6.09 & 1.00 & 1.14 \\
\hline & 3 & 一定振幅 $\left( \pm 3 \theta_{p}\right)$ & 53 & 145.8 & 2.75 & 4.08 & 0.52 \\
\hline & 4 & 一定振幅 $\left( \pm 4 \theta_{p}\right)$ & 20 & 96.0 & 4.80 & 1.54 & 0.90 \\
\hline & 5 & 一定振幅 $\left( \pm 5 \theta_{p}\right)$ & 7 & 48.2 & 6.88 & 0.54 & 1.29 \\
\hline
\end{tabular}
におけるフランジ破断によってエネルギー吸収量が決まっている.
表 4 文献 9),10) の実験結果

図 17(b) および 19(b) に, 表 4 の結果を本実験結果と併せてプロッ トしている. 文献 9)，10）の実験結果に対しても本論文の関係式が 成立つことがわかる。

\section{6 結}

$\mathrm{H}$ 形断面鋼梁について, 繰返し載荷履歴とエネルギー吸収能力の 関係を明らかにすることを目的として一連の実験を行った，梁の安 定限界が局部座屈で決まる場合 (局部座屈崩壊型) と仕口部フランジ の破断で決まる場合（破断崩壊型）を対象とし, 載荷は, 単調載荷, 漸増繰返し載荷, パターン繰返し載荷の他, 地震応答時を想定した ランダム繰返し載荷も対象とした，実験に基づき以下の結論を得た。

1) 耐力上昇率（最大耐力と全塑性モーメントの比）について，既往 の文献による評価値は局部座屈崩壊型, 破断崩壊型の場合共に実 験結果のほぼ下限に対応しており,これらの耐力評価法は妥当で ある.

2) 同一形状の試験体について, 載荷履歴を変えた場合のスケルトン 曲線と単調載荷曲線を最大荷重に達するまでの曲線で比較する と, 局部座屈崩壊の場合は載荷履歴によりスケルトン曲線がやや 異なり，スケルトン曲線は単調載荷曲線に比べ塑性剛性が若干上 昇する傾向がみられる，一方破断崩壊型の場合は，両者はよく一 致している.

3) 半サイクルで吸収するエネルギーの平均值を振幅の指標とし, 実 験に基づき, 部材が安定限界に至るまでの, 振幅と半サイクル繰 返し数の関係を導いた。

4) 標準漸増繰返し載荷 (図 6，I2) または単調載荷によるエネルギー 吸収能力に基づき，任意の繰返し載荷を受けるときのエネルギー 吸収能力を予測する式 (式 (11), (12)) を導いた.

断面の幅厚比, 仕口部の耐力上昇率, 繰返し数等が本実験の範囲 を超える場合の予測式の適用性については今後の課題である.

\section{謝辞}

本研究の一部は H18-19 年度科学研究費補助金 (基盤研究 (C) 課題 番号:18560557 研究代表者:山崎真司)の補助を受けた。また，実験 に関して東京都立大学大学院生柳沼大樹君 (現松田平田設計), 首都 大学東京大学院生羽田和樹君 (現日本設計) の協力を得た。記してこ こに謝意を表する。

注

注1)ランダム絽返し載荷

梁降伏型骨組モデル (四注1)に対する地震応答解析を行い, その時の梁 の変位応答に基づき载荷履歴を設定する，骨組の固有周期と入力地震波 謵元を表注1 に示す，なお G3BR-RW および G4BR-RW は図 8 の載荷履 歴を繰返し人力している. 


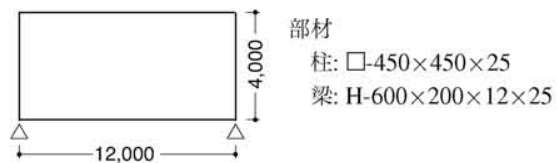

図注1 骨組モデル

表注1 固有周期と入力地震波

\begin{tabular}{|c|c|c|c|c|}
\hline 載荷名 & 固有周期 & 地震波 & 種類 & 有効継続時間 \% \\
\hline RE & $1 \mathrm{~s}$ & EL CENTRO NS & 観測波 & $24.4 \mathrm{~s}$ \\
\hline RW & $3 \mathrm{~s}$ & KK-WOS-EW $^{16)}$ & 模擬地震波 & $179.4 \mathrm{~s}$ \\
\hline RS & $3 \mathrm{~s}$ & C-SAN-EW $^{16)}$ & 模擬地震波 & $120.0 \mathrm{~s}$ \\
\hline
\end{tabular}

注2) 提案する推定式 (本文式 (11), (12)) の設計における部材性能検討への 適用として以下の方法が考えられる。

i) 部材性能検討用の有効吸収エネルギー $\left(\eta_{e_{m}}\right)$ と有効半サイクル数 $\left(N_{e m}\right)$ 部材レベルの弾塑性地震応答解析を行えば, 検部対象部材の有効吸 収エネルギー, 有効半サイクル数が得られる. 複数の設計用入力地震 動に対する解析結果に基づき, 検討用の有效吸収エネルギー $\left(\eta_{e_{m}}\right)$ と 有効半サイクル数 $\left(N_{e m}\right)$ を設定する. $\eta_{e_{m}}$ は過大に, $N_{e m}$ は過小に 評価すれば安全側である。

ii) 当該部材について参照可能な実験データを有する場合の検討方法 a 標準的漸増変位振幅繰返し截荷実験データが参照可能な場合

実験結果による $N_{I}, \eta_{I}$ およびi)による $N_{e m}$ をそれぞれ式 (11)

の $N_{I}, \eta_{I}, N_{e}$ に代入し, $\eta_{e}$ を求める.

b 単調載荷実験ダータが参照可能な場合

実験結果による $\eta_{0}$ およびi) による $N_{e m}$ をそれぞれ式 (12)の $\eta_{0}, N_{e}$ に代入し, $\eta_{e}$ を求める.

$\mathrm{a}$ またはbで求めた $\eta_{e}$ に対し, $\eta_{e}>\eta_{e_{m}}$ であれば当該部材は必要 なエネルギー吸収能力を有すると予測される.

iii) 当該部材について参照可能な実験デー夕を有しない場合の検討方法 単調载荷時の $\eta_{0}$ を既往の文献に基づき推定する.

a 局部座屈で限界づけられる $\eta_{0}$ の推定

例えば文献 3) に基づき推定する.

$\mathrm{b}$ 仕口部の破断で限界づけられる $\eta_{0}$ の推定

例えば文献 14) に基づき耐力上昇率を推定し，耐力上昇率を用い て文献 17) に基づき $\eta_{0}$ を推定する.

上記の 2 種の $\eta_{0}$ の小さい方の值を単調載荷時の $\eta_{0}$ とする.

以下 ii) b の場合と同様。

\section{参考文献}

1）田淵基嗣，坂本真一，金谷弘，藤原勝義，上場輝康: 角形鋼管柱に接合 される $\mathrm{H}$ 形はり端部の曲げ耐力の評価，日本建築学会構造系論文集， No.389, pp.122-131, 1988.7

2) 日本建築学会近畿支部鉄骨構造部会: 通しダイアフラム形式で角形銅管 柱に接合される $\mathrm{H}$ 形鋼梁の塑性変形能力に関する実大実験, 1997.7

3) 加藤勉, 秋山厷, 带洋一: 局部座屈を伴う H形断面部材の変形, 日本建 築学会論文報告集, No.257, pp.49-57, 1977.7

4) 加藤勉, 中尾雅躬: 局部座屈に支配される $\mathrm{H}$ 形断面鋼部材の耐力と変形 能力, 日本建築学会構造系論文集, No.458, pp.127-136, 1994.4

5) 日本建築学会: 耐震設計における保有酎力と変形性能 (1990), 1990.10

6) 見波進，山崎真司，松野互吾: 長周期地震動を受ける鋼構造超高層建 筑の耐震性能評価に関する考察，鋼構造年次論文報告集，pp.379-386， 2006.11

7) 山崎真司，見波進，柳沼大樹: 繰返し曲げを受ける鋼梁のエネルギー吸 収能力 その 1 , その 2 , 日本建築学会大会学術講演梗概集, C-1 分冊, pp.739-742, 2007.8

8) 栗原彩, 山崎真司，見波進，羽田和樹: 繰返し曲げを受ける鋼梁のエネ ルギー吸収能力その 3 , その 4 , 日本建築学会大会学術講演梗概集, C-1 分冊, pp.1053-1056, 2008.9

9) 松本由香，片山浩一，田中真弥: 繰返し载荷による鉄骨梁の損伤度に関 する実験的研究 (その 1) (その 2), 日本建築学会大会学術講演梗概 集, C-1 分冊, pp.563-566, 2008.9

10) 山田哲, 角野大介, 焦瑜, 島田侑子, 吉敷祥一: 繰り返し荷重を受ける 梁部材のエネルギー吸収能力（その1）（その 2), 日本建築学会大会 学術講演梗概集, C-1 分冊, pp.567-570, 2008.9

11) 建築研究所, 日本鉄鋼連盟: 鋼構造建築物の構造性能評価試験法に関す る研究 委員会報告書, 2002.4

12) 大井謙一, 陳以一, 高梨昌一: 変動軸力を受ける $\mathrm{H}$ 形龬柱の弾塑性挙動 に関する実験的研究，構造工学論文集，Vol.38B，pp.421-430, 1992.3

13）山崎真司，見波進: 変動軸力と繰返し水平力を受ける鋼柱の弾塑性挙動 に関する実験的研究，日本建築学会構造系論文集，No.519, pp.95-102, 1995.5

14) 日本建築学会: 鋼構造限界状態設計指針 - 同解説, pp.44-49, 1998

15) 見波進, 山崎真司，香林洋: 鋼構造梁端接合部の耐力評価，鋼構造年次 棆文報告集, pp.49-57, 2002.11

16) 日本建築学会: 長周期地震動と建築物の耐震性, 2007.12

17) 藤村啓介, 山崎真司: 鋼構造梁部材のエネルギー吸収星と梁端接合部の 必要耐力, 日本建築学会大会学術講演梗概集，C-1 分冊, pp.915-916, 1999.9 